\title{
Plant Propagation through Tissue Culture - A Biotechnological Intervention
}

\author{
Sameena Maqbool Lone*, K. Hussain, Ajaz Malik, Mudasir Magray, \\ Syed Mazahir Hussain, Majid Rashid and Syeda Farwah
}

\author{
Division of Vegetable Science, Sher-e-Kashmir University of Agriculture, Science and \\ Technology, Kashmir, 190 025, India \\ *Corresponding author
}

\section{A B S T R A C T}

\begin{tabular}{|c|}
\hline Keywords \\
\hline $\begin{array}{l}\text { Genetic } \\
\text { Transformation; } \\
\text { Somatic Cell } \\
\text { Hybridization; } \\
\text { Biotechnological } \\
\text { application; Plant } \\
\text { Tissue Culture; In } \\
\text { vitro }\end{array}$ \\
\hline Article Info \\
\hline $\begin{array}{l}\text { Accepted: } \\
20 \text { June } 2020 \\
\text { Available Online: } \\
10 \text { July } 2020\end{array}$ \\
\hline
\end{tabular}

Plant genetic transformation has become an important biotechnological tool for the improvement of many crops. A solid foundation for the fast development and implementation of biotechnology in agriculture has been provided by achievements in plant tissue culture. Plant tissue culture represents the most promising areas of application at present time and giving an out look into the future. The areas range from micropropagation of ornamental and forest trees, production of pharmaceutically interesting compounds, and plant breeding for improved nutritional value of staple crop plants, including trees to cryopreservation of valuable germplasm. It has broad applications in several areas but it is rather broadly used to include several variations, such as meristem culture for propagation of virus-free plants, protoplast culture and somatic cell hybridization for the introduction of new characteristics (salt tolerance, disease resistance, enhanced crop yield, etc.) into key species, anther/ pollen culture and ovule culture for producing haploid plants and embryo culture for embryo rescue in distant crosses. It also enables to select desirable traits directly from the culture setup, thereby decreasing the amount of space required for field trials. For species that have long generation time, or seeds that don't readily germinate, rapid propagation is possible by this method. A number of medicinally important alkaloids, anticancer drugs, recombinant proteins and food additives are produced in various cultures of plant cell and tissues. Thus, tissue culture is one of the most important part of applied biotechnology.

\section{Introduction}

Plant biotechnology is the technology which is used for getting modern product with high yield and at faster rate. Modern era of plant biotechnology started in the beginning of the $20^{\text {th }}$ century and is associated with the ability to grow plant cells and tissues in vitro, to regenerate and clone new plants and later, to modify their genetic characteristics. A technology known asplant tissue culture is being widely used for producing large number of plants at a very fast rate, with improved genetic characteristics, under the controlled environmental conditions. Thus, Plant tissue culture is the technique of in vitro cultivation of plant cells and organs, which divide and regenerate into callus or particular plant 
organs. The technique relies on (i) the totipotency - the inherent capacity of the individual cells of an organism to develop into a complete organism, (ii) the explants which is a small tissue excised from any part of the plant, (iii) the aseptic environment -to avoid contamination from microorganisms and (iv) the nutrient media - that strongly govern the growth and morphogenesis of plant tissues (Anonymous, 2020).

Plant tissue culture can also be defined as a collection of techniques used to maintain or grow plant cells, tissues or organs under sterile conditions on a nutrient culture medium of known composition. The plant material to be cultured may be cells, tissues or plant organs such as excised root tip, shoot tip, shoot bud, leaf petiole, inflorescence, anther, embryo, ovule or ovary. Thus, using the appropriate growing conditions for each explant type, plants can be induced to rapidly produce new shoots, and with the addition of suitable hormones, new roots. These plantlets or microplants can also be divided, usually at the shoot stage, to produce large numbers of new plantlets or microplants (Sub-culturing). The new plants can then be placed in soil and grown in the normal manner.

\section{Organization of tissue culture laboratory}

A sophisticated plant tissue culture laboratory should consist of the following areas;

Washing room; Inoculation room; Media preparation room; Culture/growth room

\section{Plant Tissue Culture Media Composition}

One of the most important factors governing the growth and morphogenesis of plant tissues in culture is the composition of the culture medium. Plant tissue culture media is generally composed of the following components;

\section{Macronutrients}

Macronutrients are those elements which are required in concentration $>0.5 \mathrm{mM} / 1$. These include six major elements: Nitrogen $(\mathrm{N})$, Phosphorus (P), Potassium (K), Calcium (Ca), Magnesium ( $\mathrm{Mg}$ ) and Sulphur (S), present as salts and constitute various media. Macronutrient stock solutions are generally made up at 10 times their final strength.

\section{Micronutrients}

Micronutrients are those elements which are required in concentration $<0.5 \mathrm{mM} / \mathrm{l}$. Theseinclude eight minor elements: Iron $(\mathrm{Fe})$, Manganese (Mn), Boron (B), Copper $(\mathrm{Cu})$, Zinc (Zn), Iodine (I), Molybdenum (Mo), Cobalt (Co) and Nickel (Ni).Micronutrient stock solutions are generally made up at 100 times their final strength.

\section{Carbon and energy source}

In the cultured cells or tissues, photosynthesis is inhibited and thus carbon must be added in the form of carbohydrates for tissue growth in the medium. The commonly used carbon and energy source is sucrose. The sucrose in the medium is rapidly converted into glucose and sucrose. The glucose is then utilized first followed by fructose. Sucrose is generally used at a concentration of $2-3 \%$.

\section{Organic supplements}

\section{Vitamins}

Vitamins are required by plants as catalystes in various metabolic processes. The vitamins most frequently used in cell and tissue culture media include thiamine $\left(\mathrm{B}_{1}\right)$, nicotinic Acid $\left(\mathrm{B}_{3}\right)$, pyridoxine $\left(\mathrm{B}_{6}\right)$ and myo-inositol. The concentration are in the order of 0.1 to 10 $\mathrm{mgL}^{-1}$. 


\section{Amino acids}

The cultured cells are normally capable of synthesizing all of the required amino acids, however the addition of some amino acids may be used to further stimulate cell growth. The most common sources of organic nitrogen used in culture media are amino acid mixtures like Casein hydrolysate (0.05 $0.1 \%), \mathrm{L}$ - glutamine $\left(8 \mathrm{mM} \mathrm{L}^{-1}\right), \mathrm{L}$ - cysteine $\left(10 \mathrm{mM} \mathrm{L}^{-1}\right)$.

\section{Organic extracts}

Addition of a wide variety of organic extracts such as coconut milk, yeast extract, malt extract, potato extract, protein hydrolysates, ground banana, orange juice and tomato juice, to the culture media results in favourable tissue responses. However, the success is achieved with the use of coconut milk $(5-20$ $\%)$ and protein hydrolysates $(0.05-1 \%)$.

\section{Growth regulators}

Only 2 main classes of PGRs are of special importance in plant tissue culture i.e., Auxins and Cytokinins.

Auxins: Concerned with cell division, cell elongation, formation of meristems and maintenance of apical dominance.

E.g. Natural-IAA

Synthetic - IBA, NAA, 2, 4-D, etc.

Cytokinins: Stimulates protein synthesis, stimulates cell division, induces shoot formation, induces axillary shoot proliferation, inhibits root formation and controls morphogenesis.

E.g. Natural - Kinetin, Zeatin, etc

\section{Synthetic - 6-BAP/ BA}

Others viz., gibberellins, abscisic acid and ethylene are of minor importance.

\section{Gelling agents}

Those compounds which are capable of gelling the media. Gelling agents form clear gels at relatively lower concentrations of 1.25 $-2.5 \mathrm{~g} / \mathrm{l}$. These are the valuable aids for the detection of contamination and root formation during the culture. Commonly used gelling agents are agar, agarose, gellan gums, gelrite, etc.

\section{Sterlization}

It is the procedure used for the elimination of micro-organisms. Maintenance of aseptic (free from all micro-organisms) or sterile conditions is essential for successful tissue culture procedures. Need for asepsis requires that all culture vessel, media and instruments used in handling tissues, as well as explant itself be sterilized.

\section{Sterilization procedures}

Preparation of sterile media, containers and small instruments

\section{Steam sterilization}

It is performed either in an Autoclave or domestic pressure cooker.

The standard conditions for autoclaving are $121^{0} \mathrm{C}$ with a pressure of 15 psi for 20 minutes.

It is used for sterilizing media, cotton plugs, plastic caps, water, pipettes, etc.

It is always recommended over dry sterilization.

\section{Dry sterilization}

It is performed in Hot Air oven.

It is a method of sterilizing glassware and metallic instruments in dry heat for 3 hours at $160-180^{\circ} \mathrm{C}$.

Dry goods can either be wrapped in Al foil, 
brown paper or sealed metal containers to maintain sterility.

It has the disadvantage of poor circulation of air and slow penetration of heat.

\section{Filter sterilization}

This method is used for the sterilization of heat liable compounds (amino acids, vitamins, etc.) which get destroyed during autoclaving.

\section{Ultra violet sterlization}

This method is generally used for the sterilization of disposable plastic wares into which the autoclaved media is later on dispensed.

$15-20$ minutes exposure is adequate.

\section{Maintenance of aseptic conditions}

\section{Alcohol sterilization}

It is used for sterilizing hands, laminar air flow cabinets and various instruments.

It is done with help of $70 \%$ ethanol.

\section{Flame sterilization}

This method is used for the sterilization of instruments that continuously used during manipulation work.

Instruments are soaked in $70 \%$ ethanol followed by flaming on a burner in the laminar airflow hood.

\section{Preparation of sterilized explant material}

\section{Chemical sterilization}

It is the method of eradication of microorganisms with the aid of chemicals.

The type and concentration of chemical sterilant to be used and exposure time varies with the type of explant used.

\section{Techniques of Plant Tissue Culture}

The various techniques of in vitro culture includes

\section{Seed Culture}

Growing seed aseptically in vitro on artificial media is called seed culture. It increases the efficiency of germination of seeds that are difficult to germinate or don't germinate well in vivo. It is used to raise the sterile or aseptic seedlings and to identify the plants which are resistant or tolerant to various stresses.

E.g., Orchids, Vanilla, Tomato, Chilli, etc

Case study 1 Studies on in vitro seed culture in vanilla(Kumaret al., 2014).

In this study, an experiment was carried out to examine the effects of different treatment combinations of PGR's on the in vitro micropropagation of vanilla. Seeds were cultured on standard MS media containing sucrose $(2.5 \%)$ and agar $(0.65 \%)$. Cultures were incubated in a growth chamber at a temperature of $26^{\circ} \mathrm{C}$, a $12 \mathrm{~h}$ photoperiod and 2000 lux light intensity. After 4 weeks, the germinated seeds had produced young seedlings with 5-9 leaves with a survival rate of $70-90 \%$. The seedlings after proper elongation were rooted on halfstrength MS medium added with charcoal $2 \mathrm{gl}^{-1}$ and IBA $1 \mathrm{mgl}^{-1}$.

\section{Meristem culture}

It involves the culturing of apical meristems, especially of shoot meristem in vitro on artificial media. It is also known as Meristemmingor Mericlonning. $3-5 \mathrm{~mm}$ shoot apices having several leaf primordial are selected as explants. However, when the objective is virus free plant production, the size of explant should be $<1 \mathrm{~mm}$. It makes use of single nodes or axillary buds. 
E.g., Capsicum, Tomato, Brinjal, Potato, etc

\section{Applications}

Plant propagation.

Production of virus free planting material.

Case study 2. Meristem Culture of Potato (SolanumtuberosumL.cv. Desiree) for Production of Virus-Free Plantlets (Zaman et al., 2018).

This study was conducted to evaluate the effect of 3 different auxins NAA, IAA and IBA each at four levels $(0,0.1,0.5$ and 1 $\mathrm{mg} / \mathrm{l})$ on meristem culture of potato for the production of virus-free plantlets. Cultures were incubated in a growth chamber at a temperature of $22-25{ }^{\circ} \mathrm{C}$ and 2500 lux light intensity. After 2-3 weeks, plantlets were studied for various parameters and transferred to greenhouse.

\section{Bud culture}

It is of 2 types;

Single Node Culture (SNC): Here, a nodal segment is isolated from the third and fourth nodes from the stem apex.The bud is then allowed to develop on a nutrient media, with the purpose of forming a shoot. Most commonly used method for propagating plants in vitro.

Axillary Bud Culture: Here, an axillary shoot bud is isolated from a plant. The bud is then allowed to develop under the influence of a relatively high cytokinin concentration. High cytokinin concentration stops the apical dominance and allows axillary buds to develop.

E.g., Potato, Tomato, Chilli, Capsicum, etc

\section{Applications}

Simple and quick method of plant propagation

In most cases, organogenesis occurs directly i.e., without callus formation.

Favors high multiplication frequency coupled with genotypic uniformity of the plants produced.

Case study 3. In vitro Micropropagation of Potato cultivars (Solanum tuberosumL.) (Xhulajet al., 2019).

This study was conducted to standardize the protocol for in vitro micropropagation of potato (Solanum tuberosumL.) cultivars by using sprouts as explant. Explants were cultured on standard MS media containing sucrose (3\%), agar (0.6\%), Calcium D pantothenate $(2 \mathrm{ppm})$ and $\mathrm{GA}_{3}(0.25 \mathrm{ppm})$. Cultures were incubated in a growth chamber at a temperature of $25 \pm 1^{0} \mathrm{C}$, a photoperiod of 16/8 hourlight/ dark and 2000 lux light intensity. Young seedlings were obtained after 3-4 weeks of inoculation with a survival rate of $80-90 \%$.

\section{Callus culture}

Callus is an undifferentiated, tumor-like mass of cells. In vitro culturing of callus tissue aseptically on artificial media is known as Callus culture. Regeneration via callus culture involves 2 important processes;

De-differentiation - the non-dividing quiescent cells of explant are reverted to meristematic state by placing on nutrient media. It results in the formation of undifferentiated mass of cells (Callus).

Re-differentiation - the de-differentiated of cells or callus undergo differentiation i.e., shoot \& root formation and develops capacity to regenerate into the complete plant. 
E.g. Potato, Tomato, Chilli, Capsicum, Brinjal, etc.

Case study 4. In vitro micropropagation of Capsicum chinenseJacq. (Gayathriet al., 2015).

The study was conducted to studythe effect of plant growth regulators in different concentration with combination for the regeneration of multiple shoot proliferation and callus induction in Capsicum chinense Jacq. by using Shoot tip, axillary buds, leaves, nodal and inter-nodal parts as the explants. Explants were cultured on MS basal medium containing sucrose (3\%), phytagel $(0.4 \%)$ and different combinations of BAP, NAA and 2,4D. Cultures were incubated in a growth chamber at a temperature of $24 \pm 2{ }^{0} \mathrm{C}$, a $16 / 8 \mathrm{~h} \mathrm{light/dark}$ cycle and 3000 lux light intensity. Callus formation was observed after 2 weeks of inoculation. Among all the explants, leaves showed $90 \%$ capacity for the formation of callus.

\section{Cell culture}

It is also called Cell Suspension Culture. It consists of single isolated cells or cell aggregates dispersed and growing in moving liquid media. It is normally initiated by transferring pieces of explant/ undifferentiated and friable calluses to a liquid medium which is continuously agitated by a rotary shaker to provide aeration and dispersion of cells.

E.g., Capsicum frutescens(CapsaicinPungency), Saffron (crocin\&picrocrocin medicinal importance), Dioscorea spp. (Diosgenin), Vanilla spp. (vanillin- flavouring chemical), 3-N-Butyl-pthalide in Celery (Effective against hypertension), etc.

\section{Applications}

Large scale clonal propagation through embryogenic cell suspension.

Somatic embryos from cell suspensions can prove useful for long-term storage in germplasm banks.

Somatic embryos from cell suspensions produce the same flavour compounds or secondary metabolites as present in the mature plant.

\section{Organ culture}

In organ culture, two in vitro methods have been used;

Ovule culture - it refers to the culture of excised ovaries and ovules.

Anther culture - It refers to the culture of excised anthers and pollens.

\section{Anther culture}

Anther culture is the aseptic excision and culturing of developing anthers from unopened flower buds in a nutrient medium, where pollen grains are induced to produce callus or embryoids and finally to haploid plantlets. The process by which haploid plant develops from male gametophyte is called androgenesis. It has been observed that uninucleate microspores midway between the tetrad release and the first pollen mitosis are the most responsive.

\section{Applications}

Simple, quick and efficient technique of haploid production.

Reduction of time in developing variety of cross-pollinated crop.

Fixation of heterosis through dihaploid production.

Induction of genetic variability.

Case study 5. Studies on Anther Culture in tomato (Solanum lycopersicumL.) (Shereet al., 2009) 
The present investigation has been undertaken using 3 varieties of tomato; Vaishali, Wild cultivar and Pusa ruby. Unopened flower buds of different sizes viz., 2-4mm, 5-6mm and 8$10 \mathrm{~mm}$ of each of the 3 cultivars were selected. Anthers were excised from flower buds and inoculated in petri-dish containing the suitable media. Dishes were exposed to cold treatment at $8{ }^{0} \mathrm{C}$ for 2,4 and 10 days. After cold treatment incubation was done in dark at $23 \pm 1{ }^{0} \mathrm{C}$.

\section{Results and Discussion}

Flower bud size of $2-4 \mathrm{~mm}$ was significantly superior over other 2 sizes.

Earlier callus initiation was observed in Vaishali (26 days) followed by Pusa ruby (27 days) and Wild (29 days).

Plant regeneration was observed on MS media supplemented with BAP $(2 \mathrm{mg} / \mathrm{l})$ and NAA (1 mg/l).

\section{Microspore culture}

Microspore or the immature pollen can be used as the explant to get the haploid plants directly. For pollen or microspore culture, the flower buds are collected, surface sterilized and the anther lobes are dissected out from the flower buds. Then the anther lobes are squeezed with the help of a scalpel within a tube or small beaker to collect the microspore or pollen in nutrient media. Then the anther tissue debris is removed by filtering the suspension through a nylon sieve with a diameter slightly larger than the pollen size $(40 \mu-100 \mu)$ allowing the microspore only to pass through it.

Then, the microspore-suspension is washed and concentrated to a plating density. The microspores obtained are then mixed with an appropriate culture medium at a density of $10^{3}-10^{4}$ microspore $\mathrm{ml}^{-1}$, and plated in small petriplate. To ensure good aeration, the layer of liquid in the dish should be as thin as possible, and sealed with 'parafilm' to avoid dehydration. The responsive pollen will divide and form embryos or calli which directly or indirectly will form the haploid plantlet. By following the method of subculturing the whole plant suitable for soil transfer can be obtained.

\section{Applications}

The explants i.e., microspores or pollens are all haploid cells.

The sequence of androgenesis can be observed starting from a single cell.

The microspores are ideal for uptake, transformation and mutagenic studies, and the microspores are evenly exposed to chemicals and physical mutagens.

Higher yields of plants/anther could be obtained.

\section{Double haploidy}

Haploid plants obtained either from anther or ovule culture may grow normally under in vitro conditions up to the flowering stage but viable gametes are not formed. Also, there is no seed set due to the absence of one set of homologous chromosomes.

The only mechanism for perpetuating the haploids is by duplicating the chromosome no. in order to obtain homozygous diploids. Diploidization is achieved by immersing very young haploids in a filter sterilized solution of colchicine $(0.4 \%)$ for $2-4$ days, followed by their transfer to the culture medium for further growth. In this procedure, chromosome or gene instabilities are minimal compared to other methods of chemical treatment.

\section{Embryo culture}

It consists of isolation of immature or mature embryos under aseptic conditions and culturing it on nutrient media.

E.g., Legumes (Green gram, Black gram, 
French bean, Soybean, etc.), Tomato, Brinjal, Potato, Turnip, etc.

\section{Applications}

Embryo rescue in case of $F_{1}$ hybrids obtained through wide/ distant hybridization.

Propagation of seeds having short viability i.e., low to negligible amount of endosperm. Shortening of breeding cycle.

\section{Somatic hybridization}

It isalso known as Parasexual Hybridization as the procedure eliminates gametes in hybridization procedure. It is also referred as Protoplast Fusion, as it involves fusion of protoplast of 2 species. It is a technique in which the protoplast belonging to different species, genera or families are fused together to form hybrid product (Heterokaryon) under in vitro conditions. Protoplasts are naked plant cells i.e., without cell wall. They are produced by subjecting the plasmolysed cells to the treatment of mixture of enzymes (cellulose \& pectinases).Culture medium of protoplasts is similar to PTC but devoid of ammonium and increased concentration of Ca.

\section{Methods of Protoplast fusion}

Polyethylene Glycol Method
Suspend the protoplasts in $1 \mathrm{ml}$ solution of Polyethylene Glycol.

Shake the culture tubes for 5 seconds and left undisturbed for $10-15$ minutes.

Wash the protoplast material several times to remove Polyethylene Glycol and then resuspend it in culture medium.

\section{Treatment with sodium nitrate}

Suspend the isolated protoplasts in $10 \%$ Sucrose solution.

Incubate the solution containing protoplasts in a water bath at $35^{\circ} \mathrm{C}$ for $5 \mathrm{~min}$.

Centrifuge the sample at $200 \mathrm{xg}$ for 5 minutes. Decant the supernatant and transfer the protoplast pellet to a water bath at $30^{\circ} \mathrm{C}$ for 30 min.

Decant the aggregating mixture and replace it with the culture medium containing $0.1 \%$ $\mathrm{NaNO}_{3}$.

Left the protoplasts undisturbed for sometime and wash twice with culture medium and plate.

\section{Electrofusion}

In this technique, protoplasts are placed in a small culture cell containing electrodes and an extremely short wave electric shock is applied, which induces the fusion of protoplasts.

Table.1 History of Plant Tissue Culture

\begin{tabular}{|c|c|c|c|}
\hline S.No. & Year & Scientist & Contribution \\
\hline 1. & 1902 & G. Haberlandt & Proposed concept of in vitro cell culture. \\
\hline 2. & 1904 & Hanning & Cultured embryos from several cruciferous species. \\
\hline 3. & 1922 & Kolte\& Robbins & Successfully cultured root and stem tips. \\
\hline 4. & 1926 & Went & Discovered first plant growth hormone - IAA. \\
\hline 5. & 1934 & White & $\begin{array}{l}\text { Introduced vitamin B as growth supplement in tissue } \\
\text { culture media for tomato root tip. }\end{array}$ \\
\hline 6. & 1939 & R.J Gautheret & $\begin{array}{l}\text { Successfully cultured cells of carrot on synthetic } \\
\text { media and reported that growth regulators and } \\
\text { vitamins, if added to media enhance the growth of }\end{array}$ \\
\hline
\end{tabular}




\begin{tabular}{|c|c|c|c|}
\hline & & & forming callus. \\
\hline 7. & 1941 & Van Overbeck & $\begin{array}{l}\text { Demonstrated for the first time the stimulatory effect } \\
\text { of coconut milk on embryo development and callus } \\
\text { formation in Datura. }\end{array}$ \\
\hline 8. & 1946 & Ball & Raised whole plants of Lupinusby shoot tip culture. \\
\hline 9. & 1954 & Muir & Breaks callus tissues into single cells. \\
\hline 10. & 1955 & Skoog \& Miller & Discovered kinetin as cell division hormone. \\
\hline 11. & 1957 & Skoog \& Miller & $\begin{array}{l}\text { Proposed Auxin - Cytokinin Hypothesis i.e., by } \\
\text { changing the relative concentrations of the two } \\
\text { substances (Auxins and Cytokinins) in the medium } \\
\text { could regulate the organ differentiation. }\end{array}$ \\
\hline 12. & 1959 & Reinert\& Steward & $\begin{array}{l}\text { Demonstrated regeneration of embryos from callus } \\
\text { clumps and cell suspensions of Daucus carota. }\end{array}$ \\
\hline 13. & 1962 & Murashige\& Skoog & $\begin{array}{l}\text { Develops a nutrient medium called Murashige\& } \\
\text { Skoog Medium (MS media). }\end{array}$ \\
\hline 14. & 1964 & Guha\&Maheshwari & $\begin{array}{l}\text { Produced first haploid embryo from the pollen grains } \\
\text { of Daturainnoxia. }\end{array}$ \\
\hline 15. & 1967 & Bourgin\&Nitsch & Produced androgenic haploid plants of Nicotiana. \\
\hline 16. & 1970 & Power et al. & $\begin{array}{l}\text { Successfully achieved the regeneration of plants from } \\
\text { protoplast fusion. }\end{array}$ \\
\hline 17. & 1972 & Carlson et al. & $\begin{array}{l}\text { Produced the first somatic hybrid between } \\
\text { Nicotianagluca and } N \text {. langschorffii by fusing their } \\
\text { protoplasts. }\end{array}$ \\
\hline 18. & 1974 & Reinhard & Introduced biotransformation in plant tissue cultures. \\
\hline 19. & 1977 & Chilton et al. & $\begin{array}{l}\text { Successfully integrated } \mathrm{Ti} \text { plasmid DNA from } \\
\text { Agrobacterium tumefaciensin plants. }\end{array}$ \\
\hline 20. & 1978 & Melchers et al. & $\begin{array}{l}\text { Did somatic hybridization of tomato and potato to } \\
\text { form Pomato. }\end{array}$ \\
\hline 21. & 1981 & Larkin \&Scowcroft & Introduced the term Somaclonal variation. \\
\hline 22. & 1983 & Pelletier et al. & $\begin{array}{l}\text { Conducted inter-generic cytoplasmic hybridization in } \\
\text { Radish \& Grape. }\end{array}$ \\
\hline 23. & 1984 & Horshet al. & $\begin{array}{l}\text { Developed transgenic tobacco by transformation with } \\
\text { Agrobacterium. }\end{array}$ \\
\hline 24. & 1987 & Klienet al. & $\begin{array}{l}\text { Developed biolistic gene transfer method for plant } \\
\text { transformation. }\end{array}$ \\
\hline
\end{tabular}

Razdan, 2019

Table.2 Basic tissue culture laboratory equipments

\begin{tabular}{|c|c|c|c|}
\hline Media preparation room & $\begin{array}{c}\text { Inoculation } \\
\text { room }\end{array}$ & Culture/Growth room & $\begin{array}{c}\text { Acclimatization } \\
\text { room }\end{array}$ \\
\hline Water purification system & $\begin{array}{c}\text { Laminar Air } \\
\text { Flow }\end{array}$ & Air conditioner & Polyhouse \\
\hline Precision balances & Microscope & Lights with timer & Glasshouse \\
\hline Autoclave & Balance & Humidifier & Shading nets \\
\hline Hot plate/ stirrer & UV light & Dehumidifiers & Humidifier \\
\hline $\begin{array}{c}\text { Water filtration unit } \\
\text { pH meter }\end{array}$ & & $\begin{array}{l}\text { Temperature } \\
\text { controller }\end{array}$ & Dehumidifiers \\
\hline
\end{tabular}

Razdan, 2019 
Table.3 Stages involved in plant tissue culture

\begin{tabular}{|l|l|}
\hline Stage & Methodology involved \\
\hline Stage $\mathbf{~}$ & Selection of mother plant and its maintenance \\
\hline Stage I & Preparation of nutrient medium \\
\hline Stage II & Sterilization of nutrient media and other auto-clavable items \\
\hline Stage III & Sterilization of explant \\
\hline Stage IV & Inoculation \\
\hline Stage V & Development of plant in growth room \\
\hline Stage VI & Sub-culturing of shoots \\
\hline Stage VII & Hardening of micro plants \\
\hline
\end{tabular}

Razdan, 2019

Table.4 Composition of Macronutrients in Different Tissue Culture Media

\begin{tabular}{|c|c|c|c|c|c|c|c|c|}
\hline Macronutrients(mgl $\left.{ }^{1-}\right)$ & MS & $\mathbf{G}_{5}$ & $\mathbf{W}$ & LM & VW & KM & M & $\mathbf{N N}$ \\
\hline $\mathrm{Ca}_{3}(\mathrm{PO} 4)_{2}$ & & & & & 200.0 & & & \\
\hline $\mathrm{NH}_{4} \mathrm{NO}_{3}$ & 1650.0 & & & 400.0 & & & & $\mathbf{7 2 0 . 0}$ \\
\hline $\mathrm{KNO}_{3}$ & 1900.0 & 2500.0 & 80.0 & & 525.0 & 180.0 & 180.0 & 950.0 \\
\hline $\mathrm{CaCl}_{2} \cdot \mathbf{2} \mathrm{H}_{2} \mathrm{O}$ & 440.0 & 150.0 & & 96.0 & & & & 166.0 \\
\hline $\mathrm{MgSO}_{4} .7 \mathrm{H}_{2} \mathrm{O}$ & 370.0 & 250.0 & 720.0 & 370.0 & 250.0 & 250.0 & 250.0 & 185.0 \\
\hline $\mathrm{KH}_{2} \mathrm{PO}_{4}$ & 170.0 & & & 170.0 & 250.0 & 150.0 & 150.0 & 68.0 \\
\hline$(\mathrm{NH} 4)_{2} \mathrm{SO} 4$ & & 134.0 & & & 500.0 & 100.0 & 100.0 & \\
\hline $\mathrm{NaH}_{2} \mathrm{PO}_{4} \cdot \mathrm{H}_{2} \mathrm{O}$ & & 150.0 & 16.5 & & & & & \\
\hline $\mathrm{CaNO}_{3} \cdot 4 \mathrm{H}_{2} \mathrm{O}$ & & & 300.0 & 556.0 & & 200.0 & 200.0 & \\
\hline $\mathrm{Na}_{2} \mathrm{SO}_{4}$ & & & 200.0 & & & & & \\
\hline KCl & & & 65.0 & & & & & \\
\hline $\mathrm{K}_{2} \mathrm{SO}_{4}$ & & & & 990.0 & & & & \\
\hline $\mathrm{Ca}_{3}(\mathrm{PO4})_{2}$ & & & & & 200.0 & & & \\
\hline
\end{tabular}

*MS = Murashige and Skoog Medium;G5= Gamborg $\mathrm{B}_{5}$ Medium; $\mathrm{W}=$ White's Medium; LM= Linsmaier and Skoog Medium;VW = Vacin and Went Medium;KM = Kao and Michayluck Medium;M= Medium 199; NN = Nitsch and Nitsch Medium. Razdan, 2019

Table.5 Composition of Micronutrients in Different Tissue Culture Media

\begin{tabular}{|c|c|c|c|c|c|c|c|c|}
\hline Micronutrients $\left(\mathrm{mgl}^{\mathbf{1}^{-}}\right.$) & MS & $\mathbf{G}_{5}$ & $\mathbf{W}$ & LM & VW & KM & M & NN \\
\hline KI & 0.83 & 0.75 & 0.75 & & & 80.0 & $\mathbf{0 . 0 3}$ & \\
\hline $\mathrm{H}_{3} \mathrm{BO}_{3}$ & 6.20 & 3.0 & 1.5 & 6.2 & & 6.2 & 0.6 & 10.0 \\
\hline $\mathrm{MnSO}_{4} \cdot 4 \mathrm{H}_{2} \mathrm{O}$ & 22.30 & & 7.0 & & 0.75 & 0.075 & & 25.0 \\
\hline $\mathrm{MnSO}_{4} \cdot \mathrm{H}_{2} \mathrm{O}$ & & 10.0 & & 29.43 & & & & \\
\hline $\mathrm{ZnSO}_{4} \cdot 7 \mathrm{H}_{2} \mathrm{O}$ & 8.6 & 2.0 & 2.6 & 8.6 & & & 0.05 & 10.0 \\
\hline $\mathrm{Na}_{2} \mathrm{MoO}_{4} \cdot 2 \mathrm{H}_{2} \mathrm{O}$ & 0.25 & 0.25 & & 0.25 & & 0.25 & 0.05 & 0.25 \\
\hline $\mathrm{CuSO}_{4} .5 \mathrm{H}_{2} \mathrm{O}$ & 0.025 & 0.025 & & 0.25 & & 0.025 & & 0.025 \\
\hline $\mathrm{CoCl}_{2} \cdot 6 \mathrm{H}_{2} \mathrm{O}$ & 0.025 & 0.025 & & & & 0.025 & & \\
\hline $\mathrm{Co}\left(\mathrm{NO}_{3}\right)_{2} \cdot 6 \mathrm{H}_{2} \mathrm{O}$ & & & & & & & 0.05 & \\
\hline $\mathrm{Na}_{2}$ EDTA & 37.3 & 37.3 & & 37.3 & & 74.6 & 37.3 & 37.3 \\
\hline $\mathrm{FeSO}_{4} .7 \mathrm{H}_{2} \mathrm{O}$ & 27.8 & 27.8 & & 27.8 & & 25.0 & 27.8 & 27.8 \\
\hline $\mathrm{MnCl}_{2}$ & & & & & & 3.9 & 0.4 & \\
\hline $\mathrm{Fe}\left(\mathrm{C}_{4} \mathrm{H}_{4} \mathrm{O}_{6}\right)_{3} \cdot 2 \mathrm{H}_{2} \mathrm{O}$ & & & & & 28.0 & & & \\
\hline
\end{tabular}

*MS = Murashige and Skoog Medium; G5= Gamborg B 5 Medium; W = White's Medium; LM= Linsmaier and Skoog Medium; VW = Vacin and Went Medium; KM = Kao and Michayluck Medium; M= Medium 199; NN = Nitsch and Nitsch Medium. Razdan, 2019 
Table.6 Composition of Vitamins and Other Organic Supplements in Different Tissue Culture Media

\begin{tabular}{|c|c|c|l|l|l|l|l|l|}
\hline $\begin{array}{c}\text { Vitamins and other } \\
\text { supplements(mgl }{ }^{\mathbf{1}} \text { ) }\end{array}$ & MS & $\mathbf{G}_{5}$ & $\mathbf{W}$ & $\mathbf{L M}$ & $\mathbf{V W}$ & $\mathbf{K M}$ & $\mathbf{M}$ & $\mathbf{N N}$ \\
\hline Inositol & $\mathbf{1 0 0 . 0}$ & $\mathbf{1 0 0 . 0}$ & & $\mathbf{1 0 0 . 0}$ & & & & $\mathbf{1 0 0 . 0}$ \\
\hline Glycine & $\mathbf{2 . 0}$ & $\mathbf{2 . 0}$ & $\mathbf{3 . 0}$ & $\mathbf{2 . 0}$ & & & & $\mathbf{2 . 0}$ \\
\hline Thiamine HCl & $\mathbf{0 . 1}$ & $\mathbf{1 0 . 0}$ & $\mathbf{0 . 1}$ & $\mathbf{1 . 0}$ & & $\mathbf{0 . 3}$ & $\mathbf{0 . 3}$ & $\mathbf{0 . 5}$ \\
\hline Pyridoxine HCl & $\mathbf{0 . 5}$ & & $\mathbf{0 . 1}$ & $\mathbf{0 . 5}$ & & $\mathbf{0 . 3}$ & $\mathbf{0 . 3}$ & $\mathbf{0 . 5}$ \\
\hline Nicotinic acid & $\mathbf{0 . 5}$ & & $\mathbf{0 . 5}$ & $\mathbf{0 . 5}$ & & & $\mathbf{1 . 2 5}$ & $\mathbf{5 . 0}$ \\
\hline Ca-D-panthothenate & & & $\mathbf{1 . 0}$ & & & & & \\
\hline Cysteine HCl & & & $\mathbf{1 . 0}$ & & & & & \\
\hline Riboflavin & & & & & & $\mathbf{0 . 3}$ & $\mathbf{0 . 0 5}$ & \\
\hline Biotin & & & & & & & $\mathbf{0 . 0 5}$ & $\mathbf{0 . 0 5}$ \\
\hline Folic acid & & & & & & & $\mathbf{0 . 3}$ & $\mathbf{0 . 5}$ \\
\hline
\end{tabular}

*MS = Murashige and Skoog Medium; G5= Gamborg B 5 Medium; W = White's Medium; LM= Linsmaier and Skoog Medium; VW = Vacin and Went Medium; KM = Kao and Michayluck Medium; M= Medium 199; NN = Nitsch and Nitsch Medium. Razdan, 2019

Table.7: Concentration and time of exposure of various sterilizing agents

\begin{tabular}{|c|c|c|}
\hline Sterilizing agent & Concentrations \% $\mathbf{\%}(\mathbf{w})$ & $\begin{array}{c}\text { Time of exposure } \\
(\mathbf{m i n})\end{array}$ \\
\hline Sodium hypochlorite $(\mathbf{N a O C C})$ & $0.1-3$ & $1-20$ \\
\hline Calcium hypochlorite $\mathbf{C a}(\mathbf{C l O})_{\mathbf{2}}$ & $1-5$ & $5-30$ \\
\hline Sodium dicholoroisocyanurate $(\mathbf{D I C A})$ & $1-2$ & $10-20$ \\
\hline Mercuric $(\mathbf{I I})$ chloride $\left(\mathbf{H g C l}_{\mathbf{2}}\right)$ & $0.1-1$ & $2-10$ \\
\hline Silver nitrate $\left(\mathbf{A g N O}_{\mathbf{3}}\right)$ & 1 & $5-20$ \\
\hline Hydrogen peroxide $\left(\mathbf{H}_{\mathbf{2}} \mathbf{O}_{\mathbf{2}}\right)$ & $10-30$ & $5-15$ \\
\hline
\end{tabular}

Chawla, 2019

Table.8 Effect of media and growth regulators on vanilla seed germination

\begin{tabular}{|c|c|c|c|}
\hline S.No. & Treatment & Media Composition & $\begin{array}{c}\text { Days taken for } \\
\text { Germination }\end{array}$ \\
\hline $\mathbf{1 .}$ & $\mathrm{T}_{1}$ & $1 / 2 \mathrm{MS}+\mathrm{BA}(1 \mathrm{ppm})+\mathrm{NAA}(0.5 \mathrm{ppm})$ & $41 \pm 2.55$ \\
\hline $\mathbf{2 .}$ & $\mathrm{T}_{2}$ & $1 / 2 \mathrm{MS}+\mathrm{BA}(0.5 \mathrm{ppm})+\mathrm{NAA}(0.5 \mathrm{ppm})$ & $42 \pm 2.18$ \\
\hline $\mathbf{3 .}$ & $\mathrm{T}_{3}$ & $1 / 2 \mathrm{MS}+\mathrm{BA}(1 \mathrm{ppm})+\mathrm{NAA}(1 \mathrm{ppm})$ & $39 \pm 2.04$ \\
\hline $\mathbf{4 .}$ & $\mathrm{T}_{4}$ & $1 / 2 \mathrm{MS}+\mathrm{BA}(0.5 \mathrm{ppm})+\mathrm{IAA}(0.5 \mathrm{ppm})$ & $41 \pm 2.17$ \\
\hline $\mathbf{5 .}$ & $\mathrm{T}_{5}$ & $1 / 2 \mathrm{MS}+\mathrm{BA}(0.5 \mathrm{ppm})+\mathrm{IBA}(0.5 \mathrm{ppm})$ & $46.5 \pm 3.47$ \\
\hline $\mathbf{6 .}$ & $\mathbf{T}_{\mathbf{6}}$ & $\mathbf{1} / \mathbf{2} \mathbf{M S}+\mathbf{N A A}(\mathbf{0 . 5 p p m})+$ Kinetin & $\mathbf{3 5 . 5} \pm \mathbf{1 . 9 7}$ \\
\hline $\mathbf{7 .}$ & $\mathrm{T}_{7}$ & $1 / 2 \mathrm{MS}+\mathrm{NAA}(1 \mathrm{ppm})+$ Kinetin $(1 \mathrm{ppm})$ & $43.0 \pm 4.63$ \\
\hline
\end{tabular}

Kumar et al., 2014 
Table.9 Effect of different levels of auxins on meristem culture of potato

\begin{tabular}{|c|c|c|c|c|c|c|c|c|c|c|c|c|}
\hline PGR & \multicolumn{4}{|c|}{ NAA } & \multicolumn{4}{|c|}{ IAA } & \multicolumn{4}{|c|}{ IBA } \\
\hline $\begin{array}{l}\text { Level } \\
\left(\mathrm{mgl}^{-1}\right)\end{array}$ & 0 & 0.1 & 0.5 & 1.0 & 0 & 0.1 & 0.5 & 1.0 & 0 & 0.1 & 0.5 & 1.0 \\
\hline $\begin{array}{c}\text { Plantlet } \\
\text { height } \\
\text { (cm) }\end{array}$ & 5.0 & 7.9 & 8.3 & 7.3 & 5.1 & 6.2 & 6.8 & 7.2 & 5.3 & 6.5 & 7.2 & 7.7 \\
\hline $\begin{array}{c}\text { No. of } \\
\text { nodes } \\
\text { plantlet }^{-1}\end{array}$ & 5.5 & 6.6 & 7.3 & 6.4 & 4.5 & 5.6 & 6.0 & 7.1 & 5.2 & 6.7 & 6.1 & 7.3 \\
\hline $\begin{array}{l}\text { No. of } \\
\text { leaves } \\
\text { plantlet }^{-1}\end{array}$ & 6.6 & 7.7 & 8.9 & 8.3 & 4.6 & 5.7 & 7.0 & 7.6 & 5.0 & 7.9 & 7.1 & 7.3 \\
\hline $\begin{array}{c}\text { Root } \\
\text { length } \\
(\mathbf{c m})\end{array}$ & 1.7 & 2.3 & 3.2 & 3.8 & 2.4 & 3.3 & 3.3 & 4.2 & 2.3 & 2.7 & 1.8 & 3.0 \\
\hline $\begin{array}{c}\text { No. of } \\
\text { roots } \\
\text { plantlet }^{-1}\end{array}$ & 10 . & 12.0 & 12.6 & 20.1 & 9.2 & 12.0 & 15.0 & 13.6 & 10.0 & 16.3 & 15.8 & 23.7 \\
\hline $\begin{array}{l}\text { No. of } \\
\text { days to } \\
\text { micro- } \\
\text { tuber } \\
\text { formation }\end{array}$ & 34.0 & 21.3 & 26.0 & 22.0 & 30.0 & 31.0 & 28.0 & 25.3 & 33.0 & 27.0 & 21.3 & 17.0 \\
\hline
\end{tabular}

Zaman et al., 2018

Table.10 Response of callus to different combination of hormones $(\mu \mathrm{M})$

\begin{tabular}{|c|c|c|c|c|c|}
\hline \multicolumn{2}{|c|}{ Combination of hormones $(\boldsymbol{\mu M})$} & Proliferation & $\begin{array}{c}\text { Percentage of } \\
\text { response }\end{array}$ & $\begin{array}{c}\text { Colour and } \\
\text { texture }\end{array}$ \\
\hline $\mathbf{B A P}$ & $\mathbf{2 , 4 - D}$ & NAA & & & \\
\hline $\mathbf{8 . 8 7}$ & - & - & Moderate & 60 & White friable \\
\hline $\mathbf{1 1 . 0 9}$ & - & - & Moderate & 67 & Soft, White friable \\
\hline $\mathbf{1 3 . 3 1}$ & - & - & Moderate & 70 & Soft, White friable \\
\hline $\mathbf{4 . 4 4}$ & 4.52 & - & High & 80 & Soft, White friable \\
\hline $\mathbf{4 . 4 4}$ & 6.78 & - & High & 83 & Soft, White friable \\
\hline $\mathbf{6 . 6 6}$ & 9.05 & - & High & $\mathbf{8 7}$ & Soft, White friable \\
\hline $\mathbf{4 . 4 4}$ & - & 5.37 & High & 83 & Pale green \\
\hline $\mathbf{4 . 4 4}$ & - & 6.71 & High & 84 & $\begin{array}{c}\text { Pale green, Hard } \\
\text { \& Off-white }\end{array}$ \\
\hline $\mathbf{6 . 6 6}$ & - & 8.06 & High & $\mathbf{8 7}$ & $\begin{array}{c}\text { Pale green, Hard } \\
\text { \& Off-white }\end{array}$ \\
\hline
\end{tabular}


Table.11 Resistant Traits transferred to hybrid species through embryo rescue technique

\begin{tabular}{|l|l|}
\hline Crossing species & Resistance trait (S) \\
\hline Lycopersiconesculentum $\boldsymbol{x}$ L. peruvianum & Virus, fungi \& nematodes \\
\hline Solanum melongena $\boldsymbol{x}$ S. khasianum & Brinjal shoot and fruit borer \\
\hline Solanum tuberosum $\boldsymbol{x}$ S. etuberosum & Potato leaf roll virus \\
\hline Brassica napus $\boldsymbol{x}$ Raphanobrassica & Shattering resistance \\
\hline Brassica oleracea $\boldsymbol{x}$ B. napus & Triazine resistance \\
\hline B. Napus $\boldsymbol{x}$ Brassica oleracea & Cabbage aphid \\
\hline
\end{tabular}

Chawla, 2019

Table.12 Genetic traits transferred via Somatic Hybridization

\begin{tabular}{|c|c|c|}
\hline CROP & CROSSING SPECIES & TRAITS \\
\hline \multirow[t]{2}{*}{ Tomato } & $\begin{array}{l}\text { Lycopersiconesculentu.m } \\
\text { peruvianum }\end{array}$ & $\begin{array}{l}\text { TMV, Spotted wilt virus \& Cold } \\
\text { tolerance }\end{array}$ \\
\hline & Solanum lycopersicoides $x$ L. esculentum & CMS (Cybrids) \\
\hline Brinjal & Solanum melongena $x$ S. sysimbrifolium & Nematode resistance \\
\hline \multirow[t]{2}{*}{ Potato } & Solanum tuberosum $x$ S. chacoense & Late blight \& Potato virus $\mathrm{X}$ \\
\hline & S. Circalifolium $x$ Solanum tuberosum & Frost resistance \\
\hline Cabbage & $\begin{array}{l}\text { Brassica oleracea var. capitata } x \text { B. } \\
\text { oleracea }\end{array}$ & Cold tolerance \\
\hline Watermelon & Citulluslanatus $x$ Cucumismelo & Club rot resistance \\
\hline Radish & Raphanussativus $x$ Brassica napus & Club rot resistance \\
\hline Carrot & Hordeumvulgare $x$ Daucus carota & Frost \& salt tolerance \\
\hline
\end{tabular}

Razdan, 2019

\section{Applications}

To produce novel interspecific and intergeneric crosses between plants that are difficult or impossible to hybridize conventionally.

To produce fertile diploids and polyploids from the protoplasts of sexually sterile plants. In vitro fusion of protoplast opens a way of developing unique hybrid plants by overcoming the barriers of sexual incompatibility.

To produce transgenic plants through genetic transformation of protoplasts.

\section{Cybrids}

These are the genotypes having nucleus from one of the parents but the cytoplasms of both the parents.This process of protoplast fusion which results in the development of cybrids is known as Cybridization. This type of hybridization is obtained by inactivating the nucleus of one of the protoplasts.The inactivation is achieved by either the application or treatment with Iodoacetate.Herbicide resistance and CMS have been transferred by this method in Tobacco and Tomato.

Advantages of plant tissue culture technique

Mass multiplication of elite clones.

Beneficial when conventional propagation is difficult.

Plants can be produced or multiplied in large numbers in a shorter period of time from small vegetative parts 
Micropropagation is not season dependent because the controlled conditions in the Tissue Culture Laboratory permits the year round production of tissue culture plants in "season-controlled" growth rooms, where environmental conditions are set for optimal regeneration and growth.

Plants produced through micropropagation may have increased branching and flowering, greater vigour and higher yield, mainly due to the possibility of elimination of diseases.

Plant cultures in approved media are easier to export than the soil- grown plants.

\section{Disadvantages of plant tissue culture technique}

During the course of micro propagation, several slow-growing microorganisms (e.g.Eswinia sp., Bacillus sp.) contaminate and grow in cultures that will adversely influence propagation of plants.

Micro propagation of certain plants is often associated with accumulation of growth inhibitory substances in the medium. Chemically, these substances are phenolic compounds, which are toxic, turns the medium into dark colour and can inhibit the growth of tissues (Brewing of media).

During the course of repeated in vitro shoot multiplication, the cultures exhibit water soaked or almost translucent leaves. Such shoots do not grow and even may die.

In conclusion the total, it has been estimated that in India more than Three hundred and fifty million tissue cultured plants are being produced annually through tissue culture method. In India, tissue culture is rapidly becoming a commercial method for propagating new and rare species, difficult-topropagate plants, healthy, virus free and trueto-type plants.Plant production can be carried out throughout the year, irrespective of season and weather, which solves farmers' climatic plantation problems. Permits germplasm exchange and distribution throughout the world. Tissue culture activity is taking a shape of an industry as many farmers are planting tissue culture grown plantlets; agrotraders are buying and selling tissue culture grown plantlets while some are exporting either the plantlets or the produces of plants grown by tissue culture, especially varieties of potato like $K$. jyoti, $K$. Giriraj, etc. are enjoying high profits in Punjab. Plant cell and tissue cultures provides a way for controlled production of myriad of useful flavor compounds and secondary metabolites. E.g. Capsaicin(Capsicum frutescens), etc.

\section{References}

Ahmed, N., Siddique, I. and Anis, M. Improved plant regeneration in Capsicum annumL.from nodal segments. Biologiaplantarum, 50 (2006):701-704.

Anilkumar, M. and Nair, A.S. Multiple shoot induction in Capsicum annuum L. cv. Early California Wonder. Plant Cell Biotechnology andMolecular Biology, 5(2004): 95-100.

Badoni, A. and Chauhan J.S. Effect of growth regulators on meristem-tip development and in vitromultiplication of Potato Cultivar "KufriHimalini". Nature and Science, 7(2009):31-34.

Chawla, H.S. Introduction to Plant Biotechnology. CBS Publishers \& Distributors, (2019).

Faria, R.T., Destro, D., Bespalhok, J.C. and Illg, R.D. Introgression of in vitro regeneration capability of Lycopersiconpimpinellifolium Mill. into recalcitrant tomato cultivars. Euphytica, 124 (2002): 59-63.

Gayathri, N., Gopalakrishnan, N. and Sekar, T.In vitro micropropagation of Capsicum Chinense Jacq. (Naga King Chili). Asian Journal of Plant Science and Research, 5(2015):13-18.

Hartmann, H., Kester, D., Davies, F. and Geneve, R. Tissue Culture Hartmann and Kester's Plant Propagation, Principles and Practices 
8th edition, (2016).

Hoque, M.E. In vitro tuberization in potato (Solanum tuberosum L.). Plant Omics Journal, 3(2010):7-11.

Kumar, V. and Naidu, M.M. Development in coffee biotechnology - in vitro plant propagation and crop improvement. Plant Cell, Tissue and Organ Culture, 87(2006): 49-65.

Kumar. Plant Tissue Culture. New Central Book Agency, (2008).

Mascarenhas, A.F. Handbook of Plant Tissue Culture. Indian Council of Agricultural Research, New Delhi, (1998).

Mathews, D.M. Sensitive detection of single and mixed viral infections in ornamental plants at all stages of the propagation cycle. Proceedings of the Third USDA-ARS Floral and Nursery Crops Researcher's Workshop, (2010): 1-3.

Murashige, T. and Skoog, F. A revised medium for rapid growth and bioassay with tobacco tissue. Physiol. Plant, 15(1962): 473-497.

Razdan, M.K. Introduction to Plant Tissue Culture Third Edition. Oxford and IBH Publishing Co, (2019).

Sanatombi, K and Sharma, G.J. Micropropagation of Capsicum annuum L. BiologiaPlantarium, 52(2008): 517-520.

Sanatombi, K. and Sharma, G.J. Micropropagation of Capsicum frutescens L. using axillary shoot explants. ScientiaHorticulturae, 113(2007): 96-99.

Sharma, J.P. Principles of Vegetable Breeding. Kalyani Publishers, (2009).

Shere, U.B. and Dhage, S.J. Studies on anther culture in tomato (Solanum lycopersicum).International Journal of Plant Sciences, 4(2009): 433-435.

Shivegowda, S. T., Mythili, J. B., Anand, L., Saiprasad, G. V. S., Gowda, R. and Gowda, T. K. S. In vitro regeneration and transformation in chilli pepper (Capsicum annuum L.). Journal of Horticultural Sciences and Biotechnology, 77(2002): 629-634.

Sharma, S., Shahzad, A., Akhtar, R. andUpadhyay, A. Micropropagation: A Boon for Conservation of Valuable Vines and Lianas. Biotechnological strategies for the conservation of medicinal and ornamental climbers, (2015): 163-193.

Thayyil, P. K., Stephen, F. and Alex, S. Studies on in vitro seed culture in vanilla.Indian Journal of Horticulture, 66(2014): 547548.

Xhulaj, D. and Ghixari, B. In vitro Micropropagation of Potato cultivars (Solanum tuberosumL.). Agriculture \& Forestry, Podgorica, 64(2019): 105-112.

Zaman, M.S., Quraishi, A., Hassan, G., Ali, S., Khabir, A. and Gul, N. Meristem Culture of Potato (SolanumtuberosumL.) for Production of Virus-Free Plantlets. Online Journal of Biological Sciences, 1(2018): 898-899.

Zhang, H. and Blumwald, E. Transgenic salttolerant tomato plants accumulate salt in foliage but not in fruit. Nature Biotechnol, 19(2001): 765-768.

\section{How to cite this article:}

Sameena Maqbool Lone, K. Hussain, Ajaz Malik, Mudasir Magray, Syed Mazahir Hussain, Majid Rashid and Syeda Farwah. 2020. Plant Propagation Through Tissue Culture - A Biotechnological Intervention Int.J.Curr.Microbiol.App.Sci. 9(07): 2176-2190. doi: https://doi.org/10.20546/ijcmas.2020.907.254 